\title{
Hierarchies of Race and Gender in the French Colonial Empire, 1914-1946 ${ }^{1}$
}

\author{
Jennifer Anne Boittin, Christina Firpo, Emily Musil Church
}

\begin{abstract}
This article looks at French Indochina, metropolitan France, and French West Africa from 1914 through 1946 to illustrate specific ways in which French colonial authority operated across the French empire. We look at how colonized people challenged the complex formal and informal hierarchies of race, class, and gender that French administrators and colonizers sought to impose upon them. We argue that both the French imperial prerogatives and colonized peoples' responses to them are revealed through directly comparing and contrasting various locales across the empire. Our case studies explore interracial families and single white women seeking compensation from the French in Indochina, black men defining their masculinity, and Africans debating women's suffrage rights.
\end{abstract}

In 1920, the French writer Lucie Cousturier published Des Inconnus chez moi, in which she recorded her World War I contacts with the tirailleurs, or West African soldiers who fought for France. ${ }^{2}$ While portions of this texther first in a series of books about Africans that became increasingly more critical of colonialism — contained conventional stereotypes of black men as savages, or children, she also occasionally started to break from this mold by challenging received notions of blackness. ${ }^{3}$ Take, for example, a conversation with one of the men to whom she was teaching French, a soldier named Damba Dia.

You say Europeans do not regard the Senegalese as they do other men? True, they say that the black man's head is not made in the same way as theirs. Maybe it's true said Damba Dia with gloom.

But maybe it's not true, because they also say that women are less intelligent than men...

What? said a startled Damba, here women are not regarded as well as men? But I have always seen women in France do the same things as men. ${ }^{4}$

In this passage Cousturier proposed first that during the Third Republic French men maintained a universalism that excluded all those of a different race or gender, and, second, that individuals who were not white and male were quite aware of the imbalance. Third, she suggested that French women had the capacity to connect with colonized men precisely because they were oppressed in a comparable manner and blocked from similar basic civil rights, most significantly the vote.

Throughout the French empire during the early twentieth century, we argue, colonized people challenged the complex formal and informal hierarchies of race, class, and gender that French administrators and colonizers imposed upon them. The colonized in turn also manipulated and reclassified such hierarchies. This article explores three different colonial spaces in French Indochina, mainland France, and French West Africa to reveal that in all of them gender and race were subtle and constantly shifting categories mediating how people related to the French empire in their daily lives. Interracial families and single white women who sought compensation from the French in Indochina during World War I, African and Antillean migrants who redefined their own masculinity in interwar France, and Africans who debated African women's suffrage rights at the close of World War II all relied upon their perceptions of these categories when confronting both one another and the state.

In the early twentieth century, the French colonial empire created systems of control that preserved French power in part by stripping authority from traditional political leaders and families. Race-based practices in the colonies privileged whites and created a racial hierarchy. ${ }^{5}$ White prestige was expressed, and white identity developed, through violence against nonwhites and was carefully guarded through barriers and fortifications in city planning schemes .6 While this regulation afforded colonizers advantages, the administration's management and regulation of white people's lives extended to their cultural practices, living standards, and even sexuality. ${ }^{7}$ In many cases, these changes meant that leadership roles in the colonies were reserved fi rst for white men and then for the colonized men who were considered to be the most assimilated to French culture. This system greatly diminished the authority of other colonized men (and women), and informed social and political 
interactions throughout the empire. From a gendered standpoint, this apparent emasculation of colonized men in both their public and personal lives shifted their relationships to, and expectations of, women. ${ }^{8}$ Thus the Third and Fourth Republics' colonial structures not only maintained white, European control, but also facilitated hierarchies based on race, gender, class, and place of origin that created competition among various colonized peoples. This structure might have simply discouraged solidarity and hindered unified challenges to French authority, but instead it permeated everyday lives until those who confronted these hierarchies not only recognized, but also often completely re-imagined them.

Today, scholars of colonialism argue for exploring how the specificity of place can influence colonial studies. Not only should metropole and colony be considered in a single analytic field, as Frederick Cooper and Ann Stoler have articulated, but the precise influence of a locality should also be considered within that analytic field. ${ }^{9}$ This methodology ideally culminates in comparative, transnational history, and thus requires a comprehensive understanding of both metropolitan and local colonial histories. Some scholars undertake such studies alone, others through edited volumes. ${ }^{10}$ In this article, we offer a third alternative, and a closer collaboration still: an article-length co-authorship considering the conceptual and theoretical implications of empire-wide uses and treatments of racial and gendered hierarchies. ${ }^{11}$

This alternative grew organically out of our individual research, after we realized during a conference panel that each of our articulations of how race and gender functioned within the French imperial context had so much in common that together they revealed the cohesive dimensions of trans-national systems of empire. ${ }^{12}$ We see its collaborative nature and focus on human interactions as a feminist project and propose that our approach offers several methodological possibilities. First, our collaboration encourages comparative juxtapositions of area studies expertise within a far broader framework, in our case through specific examples of colonizer-colonized interactions relating to race and gender. Second, this approach invites constant exchange and stimulation during intellectual processes that include both the evaluation and reconsideration of primary sources, and writing. Indeed, by drawing on a rich body of sources from four continents-including police surveillance reports, official correspondence, novels, newspapers, and personal letters-we can gain a much better understanding of the patterns and exceptions that guide both the formation of hierarchies and the categories that inform them. Moreover, we explore these patterns across time. Finally, through this approach we identify commonalities in the French colonial experience that transcended location, including the fluidity that guided French colonial ideology and policy, even while recognizing the unique specificity of each locality.

Although the post-World War I era was seen as a new start for the Republic, or a nouvelle France, ${ }^{13}$ colonial hierarchies that granted privileges based on race, gender, and territorial origin were constantly established or redefined throughout the period, a paradox that is consistently present in modern French history. ${ }^{14}$ At first glance, French Indochina was not that similar to metropolitan France between the wars. Both during and after World War I, greater liberties were available to women in mainland France who could not vote but were given a certain measure of latitude in the workplace, in various social public spaces, and through the many organizations that they established in order to demand various rights. ${ }^{15}$ Likewise, somewhat greater liberties were granted to black Africans in France, compared to those living in French West Africa. 16 In the metropole the former published newspapers largely free of censorship, socialized with white French women, and had access to a number of supporting organizations such as the French Communist Party or the Ligue des droits de l'homme, which allowed them to reach wider audiences with their demands. Still, all these rights and opportunities did not add up to the complete legal and ideological equality sought by many French women and colonized men and women. In the immediate postwar years, as the French empire sought to rebuild its imperial power in part by granting increased rights to some colonized peoples, colonized women were shut out from the promises of the new republic. 17

In colonial spaces women were considered crucial for controlling European prestige because the management of gender was essential to the expression of whiteness. 18 In an attempt to curtail interracial relationships and encourage French culture, during World War I the French colonial ad-ministration in Indochina set standards, for example through subsidies that encouraged white women to marry white men.19 Likewise, as a largely un-spoken process by which to determine autonomy and standing, masculinity defined how black men in France shaped their communities. ${ }^{20}$ Working-class black men's alternate inclusion and sidelining of black and white women within the black sociopolitical circles of interwar France, and of white-collar and intellectual colonial men, was one way for them to confront a metro-pole that largely treated migrants, colonial or not, as interlopers within a society 
dominated by white French men. Finally, after World War II both African men and white men recognized that when enfranchised, women represented an important voting demographic that could influence policy. While European men tended to resist female suffrage as a challenge to male authority, in French West Africa men fought for the inclusion of African women as a symbol of racial equality to the recently enfranchised European women. Through our investigation of relationships between colonizer and colonized, as well as among the colonized, we argue that, rather than merely positioning individuals in rigid strata, the French colonial government policies that were created to maintain social order were defied and reinterpreted by colonized people in ways that should profoundly recast our understanding of power and privilege within the French empire.

Race adds a third dimension to the constantly evolving interplay between class and gender .21 Racial discrimination —or even referring to race on a government document—was not legal in the Third Republic, but government administrators nonetheless found ways to classify races and discriminate among them .22 This cleavage between rhetoric and practice was evident in our case studies when the World War I military allocations council used cost-of -living estimates determined by race to discriminate against some French soldiers' families; through various authorities' attempts to control colonial soldiers' and workers' relationships to French women in France during and after the war; and through the French administration's reluctance to give voting rights to African women after World War II. ${ }^{23}$

This paradox between republican ideologies and discriminatory systems consistently marked France's modern history, as revealed for example through the tensions between the ideals of the civilizing mission and the limitations imposed by ground-level colonial administration studied by Alice Conklin. ${ }^{24}$ Gary Wilder reminds us that anti-racial rhetoric and racialist practices were consistent in both the metropole and the colonies throughout modern France's history, but cautions that this contradiction "should be a point of departure, not arrival" for scholars working on these questions. ${ }^{25}$ Joan Scott makes a similar argument regarding women's roles, and both direct attention to the manner in which the ideals of the 1789 Revolution in many ways delineated the categories that defined inequalities more sharply. ${ }^{26}$ Collisions between rights and practices created interstices in which hierarchies worked in several directions, we argue, so that gender and race were multifaceted.

\section{The Military Subvention Process in Colonial Cochinchina}

During World War I, the colonial government of Cochinchina, the southeastern area of the French Indochina colony, exerted its influence over the private lives of a diverse group of French citizens - whites, Vietnamese, Indians, and Eurasians. Though the French colonial mission civilisatrice was intended to be color blind, it rarely was in practice. This irony was not lost on the white women or people of color who made their voices heard, in various ways, through their communications with the military allocations council. ${ }^{27}$ When developing Cochinchina's World War I-era military subventions program, the colonial government employed the antiracist rhetoric of the mission civilisatrice for the very purpose of racial discrimination. In turn, this government influence provoked complex interactions between the colonial government and members of the colonial public.

The changes associated with World War I posed a potential threat to Cochinchina's racial and gender hierarchies. The economic distress caused by the military draft further impoverished the petits blancs (the poor white class), thereby threatening to tarnish white prestige in the colony. Meanwhile, with male heads-of-family absent, women were left in control of the households; the result was a temporary change in the structure of families with French citizenship.

To provide financial assistance to families who suffered from the loss of income formerly earned by the draftees, the colonial government of Cochinchina adopted a military subventions program that had been created in metropolitan France. Though this had not been its intention at inception, this program, as administered in the colony, had the secondary effect of helping to relieve French anxiety about a potential disruption of the colony's racial and gender order. Ann Stoler argues that in the case of the Netherlands Indies, the colonial government deliberately influenced the class status of

whites in an effort to manage the colonial racial order. ${ }^{28}$ Likewise, in French Cochinchina, the notes of the military allocations files reveal that colonial administrators meeting in Saigon consciously and unconsciously used the subjectivity of the military subventions process to advance the class status of the petits blancs at the expense of citizens of color. The military allocations council also used the subventions process to regulate the behavior of white women and thereby to prevent them from transgressing the boundaries of the traditional family 
structure. In their attempt to reinforce the colonial racial hierarchy, the allocations council members used private spaces to redefine the margins and periphery of colonial public society to include women and citizens of color. While colonial administrators ostensibly awarded subventions according to the Third Republic's ideal "without distinction of race," they in fact manipulated the republican rhetoric to make the case for white male privilege and reveal a racial hierarchy imposed on French citizens via the subvention process. The interaction between the council and the applicants reveals that French citizens did not accept this hierarchy and used the subventions process to subvert the imposed hierarchy. Three types of cases reveal this practice: first, white French women who transgressed the boundaries of "traditional" families; second, mixed-race families who transgressed both gender and cultural norms; and finally, Indian families, who challenged the colonial government on its own terms.

The military subventions program operated on an on-demand basis. Families of drafted soldiers sent applications for allocations to the Cochin china government. Applicants were required to provide a detailed assessment of their financial situation to prove that the drafting of the male family member had resulted in impoverishment. The colonial council used local police to investigate the applicants' claims, at times seeking third parties to corroborate or refute them. The third parties, often neighbors or former employers, were counted on to point out alternative sources of income and to comment on the moral conduct of the soldiers' wives.

Of all the groups represented in the World War I military allocations fi les, white French citizens received the highest military subventions, and as a result maintained an elevated class status. ${ }^{29}$ Of the demands that were granted allocation, married white women received three piastres per day plus necessary expenses for their children. Indian and Vietnamese women received 1.5 piastres or less per day. ${ }^{30}$ Divorced white women were allocated 1.25 piastres per day plus expenses for children, while divorced non-white women were given no allocations whatsoever.

The military allocations council awarded money to white French families in cases where the female heads of household maintained a traditional family structure. Women who did not play a role in supporting the traditional family were marginalized and manipulated into conforming to traditional norms. Given the lengths to which the colonial government went in its efforts to preserve the traditional French family, some divorced or abandoned women took advantage of this obsession to secure allocations in their husbands’ names. Marie Agnes B., divorced from the soldier B., was unable to support herself after her divorce. She filed for military allocations and received 1.25 piastres per day and .50 piastres for each of her children $.31 \mathrm{In}$ another case, Madame G. sought military allocations as a means of obtaining a salary in the name of the husband who had abandoned her four years earlier without bothering to divorce her.32 In the case of Madame A., her husband had abandoned her in 1911 for another woman. She learned that he was mobilized only after initiating divorce proceedings. Still legally married to him and hence eligible for his allocation, she applied to the colonial government for support, cleverly omitting that she had started divorce proceedings in order to remain eligible for the three piastres per day awarded to white married women. In the course of its investigation, the allocations council learned that she was virtually divorced and used her deception as an excuse to refuse her subvention .33

Although Mesdames B., G., and A. took advantage of the colonial al-locations system for personal financial gain, it is important to note that they did so in a way that subtly subverted the patriarchal system. In fostering the illusion that they remained in relationships with their husbands, the three women exploited the Third Republic's obsession with traditional families. This colonial obsession stifled women's autonomy and penalized them for breaking away from the marital structure, even when their husbands were neglectful or abusive, or when these men had initiated a separation. The allocations process thus became an unlikely means through which women could assert their agency, however unsuccessful.

The military subventions files reveal the inconsistencies of the Third Republic's ideals as applied to families of white French men who married Vietnamese women. These were the families of white French men; as such, they presumably should have been afforded the privileges of whiteness. On the other hand, the nontraditional racial nature and unorthodox lifestyles of these families stirred considerable anxiety among colonial administrators - and discrimination in the allocations process. The fear was that, if not held in check by the process of reduced subventions, among other things Vietnamese culture would supplant French culture in the Franco-Vietnamese family units, thus undermining the mission civilisatrice .34 
The military subventions council made its decisions by distinction of race when the wife of a white French soldier was not white. For example, when Pierre L.'s wife, T. T. Hay, filed a demand for a larger allocation, the council did "not believe it owes his wife a daily allocation of three piastres, which is only granted to European wives, "35 even though Vietnamese wives of Frenchmen were expected to uphold the family's French lifestyle, which, the council claimed, was more expensive than a Vietnamese lifestyle. The al-locations council explained that it could not "allocate more than 45 piastres per month to this military man who does not have any children and whose wife is indigène. "36

The military subventions council used the allocation judgments to punish Franco-Vietnamese families that strayed from the cultural ideal-the ideal being French and not living à l'indigène. The data on Franco-Vietnamese families is consistent with a larger trend in Indochina's politics of miscegenation during World War I. For example, the Vietnamese wife of M. B. asked for an increase in allocations to help pay for her hospital bills. She was rejected because she lived with her parents "à l'indigène., ${ }^{\text {'3 }}$ In another case, the soldier R. had a Vietnamese concubine and four children. The family fell below the poverty line, and R. requested military subventions. The council rejected his request because his "situation did not find itself modified in the least by the European war, and the existence of his family, who lives like an indigène, doesn't cost him much. "38 This is an example where the military council exerted its authority over the private life of a French citizen in order to reinforce public debates on miscegenation. In doing so, the council effectively recast the white male heads of family as outsiders in the colonial hierarchy.

Let us now turn to the Indian families who held French citizenship and migrated to Cochinchina through colonial networks such as military or trade networks. Like the Franco-Vietnamese families, Indian families that had been approved for military allocations received lower allocation sums than did white families. Indian families typically received 1.5 piastres to support a wife and up to four children-half the amount of the mandatory three piastres per day granted to French women who did not have children. ${ }^{39}$ Members of the Indian population, recognizing that their allocations were disproportionately small, issued a complaint to the French Ministry of Colonies. The complaint exposed the colony's hypocrisy in failing to uphold the empire's republican values, and the issue of Indian allocations became a battle over the interpretation of the Third Republic's tenet égalité, "without distinction of race."

The military allocations files reveal that council members deliberately placed Indian families at a financial disadvantage vis-à-vis French families. In rejecting one Sandanassamy A.’s request, a council member remarked: "The interested [party] seems to believe that the allocation is due to all the reservists"- the insinuation being that Sandanassamy A. was presumptuous to think that Indians automatically received the same subvention amount as white Frenchmen.$^{40}$ When the wife of soldier C. gave birth to another child, C. requested an increase from the 2.5 piastres that he had originally been awarded. The council rejected his request on the grounds that 2.5 piastres per day was sufficient for an Indian family with three children. ${ }^{41}$

In 1915, Indian soldiers with French citizenship lodged a collective complaint with the French Deputy from India. The deputy in turn notified the minister of colonies in Paris that the Indian families of Cochinchina were receiving only 1-1.5 piastres per day, leaving their families in a "precarious situation ."42 The Minister of Colonies agreed that this constituted a "difference of treatment that [could] not be justified."43

The issue raised by the Indian plaintiffs evolved into a debate over the meaning of "without distinction of race.” The governor of Cochinchina explained to the minister of colonies that, while the allocations council acknowledged that it should not make distinctions by race, it also believed it should consider each case "with benevolent attention and full independence"-a euphemism for permitting bias. In patronizing doublespeak, the governor explained that while the council agreed that all families-French, Indian, Vietnamese, or mixed-raceshould receive equal subventions (ninety piastres per month, which European families received), the council could only give Indian families between forty-five and fifty piastres per month because to do otherwise would be too much of a strain on the allocation budget. ${ }^{44}$ Furthermore, he reasoned, life in Cochinchina was more expensive for a European than for an Indian, so an equal distribution of allocation money would actually discriminate against Europeans. ${ }^{45}$ With this sleight of hand, the governor managed to subvert the very antidiscriminatory republican ideals he was ostensibly defending.

Cochinchina's colonial government, as manifested in its World War I-era military allocations council, faced an ideological challenge emblematic of French colonialism. On the one hand, the colonial government was held 
to the republican ideal of égalité; on the other, this government depended upon a racial hierarchy to facilitate colonial rule. In an effort to reconcile these contradictory realities, the allocations council resorted to a racialist manipulation of republican ideals. The subjective nature of the allocations process allowed the council to punish families that transgressed racial boundaries and reward those that adhered to the expectations assigned to their particular racial category.

As another means of controlling the colony's racial order, colonial officials sought to regulate the behavior of women, whom they regarded as the biological and cultural reproducers of the nation. ${ }^{46}$ As the new heads of household, women exerted a tremendous influence over their families' cultural practices and, hence, racial identity. The subjective allocation of military subvention money to the new female heads of family became a way that the World War I military allocations council—and by extension, the colonial government—managed racial categories by regulating gender roles and economic status.

Much like the following cases in metropolitan France and French West Africa, the story of colonial Cochinchina reveals the ways in which the war affected the colonial government's notions of hierarchy and resulted in subtle changes to the notions of social periphery. The experiences of wartime privations and the resulting state "benevolence" provided the space to further impose informal hierarchies of race and gender, yet it also provided the space for the colonized of Cochinchina to subtly challenge such hierarchies. Furthermore, the case in Cochinchina highlights the ways in which marginalized peoples subtly resisted the tenets of republican society that were used to justify colonialism.

\section{Black Communities, Honor, and Emasculation in the Metropole}

The fears manifested by colonial Cochinchina's administration with respect to the maintenance of both traditional family hierarchies and mono-racial relationships were confirmed by social interactions in both wartime and postwar metropolitan France. Not only overseas, but also from within France, hierarchies of race and gender were being challenged more and more openly. As in Cochin china, administrative measures were used to regulate colonial populations in France during World War I. They were somewhat successful, and many colonial workers and soldiers were expedited back overseas at the war's end, but such measures also provoked those who remained in France to reflect upon their place on the mainland ${ }^{47}$ Thus, when creating postwar communities, black men either carefully or tempestuously considered how intersections between race, gender, and class should shape them. Linking manhood, class, and politics, colonized men revealed these considerations through the language they used to chide and prod one another. Through such language these men also debated when and how white women belonged in their lives and politics. ${ }^{48}$ In black communities, white women fulfilled a role far more complex than that optimistically suggested by Lucie Cousturier as partners in oppression. Instead, the presence of white women was carefully controlled and often contested within African and Antillean communities. Seeking ways of determining authority or control over their lives, black men restructured the traditional colonial hierarchy that had buried them within its many layers. They responded to the association between sociopolitical status and sexuality confirmed by the French government during World War I by linking these questions within their communities. The establishment of anti-imperial and working-class organizations as masculine spaces in which white men were erased, white women were marginalized (but importantly present), and black intellectuals were objectionable, was one way for black male workers to assert themselves within the metropole.

In Des Inconnus chez moi, as quoted in the introduction to this article, Lucie Cousturier underscored the injustice of being denied certain civil rights as a result of categories such as race and sex. However, political rights were not the only ones denied to tirailleurs. The tirailleurs' status was also made clear by the manner in which various branches of the French administration sought to regulate their relationships with white women. Tirailleurs were introduced to France from within the domain of war, which was not an asexual domain. Thus, early on their place in France was defined not just through administrative policies regarding their freedom of movement, or limited access to political rights, but also through careful manipulation of their social and amorous spaces. The administration was adamant about quashing relationships between colonial men and white women. For example, the separation of colonial workers from metropolitan workers (many of whom were women during the war) was implemented in mainland France to try and preserve the distinction between colonial subjects or citizens and the French colonizers that had been carefully established overseas .49 Yet workers and, while on 
leave, tirailleurs, did come into contact with French women, for example through sexual and sometimes marital relationships. During, but also after the war, such relationships were closely monitored by the government.50

Censorship was designed in part to prevent soldiers in France from writing to the colonies about their trysts with French women, or, worse, mailing photographs of these white women overseas. Marriage was also strongly discouraged by the French administration. At the extreme, a military or civilian administrative representative was sent to persuade the woman's family to forbid the marriage, rationalizing that this indigène could not maintain the European woman in the lifestyle to which she was accustomed.51 This argument often failed when these women came from poorer families, or when fathers valued their daughter's honor more than financial concerns .52 In order to marry French women, colonized men had to supply difficult to procure paperwork, including birth certificates and proof of their marital status. Moreover, those who succeeded in marrying a French woman could find themselves persuaded to remain in the metropole, for example by being strongly urged to reenlist. 53 Such measures not only made clear to the colonized that relationships with French women were political, but also showed that the French administration seemed intent upon dispossessing them of their manhood, specifically by complicating their access to white women and underscoring their economic weakness vis-à-vis French men.

If the French administration's stance has been explained as resulting from its fear that such relationships might encourage colonized men to see them-selves as equals to white Frenchmen, and thus no longer blindly accepting of the latter's dominance in the imperial system, the question remains, how did colonized men respond to this politicization of their amorous relation-ships? 54 In the extreme, as discovered by a translator asked to translate from Vietnamese to French a letter written by an Indochinese soldier in Orléans, this situation could lead a colonized man who had visited a brothel to state: "I had [the prostitute] suck my dick, for my personal satisfaction. And, after, I say 'I forced the motherland of the Metropole (France) to suck the dicks of all Annamites... It's my vengeance against the despicable people.'”55 This language was used by military officials to underscore the dangers of allowing colonized men to think they were equal to French men. It also reveals how inhibiting access to French women could provoke colonized men. Yet it does little to explain how colonized men and French women engaged with one another when a business transaction was not at the heart of the social interaction.

By the mid-1920s, anti-imperial migrants had for the most part split into distinct associations, in the case of North Africans and Vietnamese men determined by origin, and in the case of black men determined largely by complex articulations of race, origin within the empire, and class. 56 Work-ing-class black men tended to congregate in anti-imperialist groups, several of which loosely succeeded one another during the interwar years, including the Comité de défense de la race noire, the Ligue de défense de la race nègre (LDRN), and the Union des travailleurs nègres (UTN). ${ }^{57}$ For the most part, the members of these groups were militant Antilleans and Africans, including some Malagasies, whose ultimate goal was independence from France. Some members were fervent communists, but many were not. Although these associations succeeded one another throughout the interwar years, and while their leaders changed on a regular basis, members remained largely the same. There were also black associations that focused instead on the possibilities for association with France. ${ }^{58}$ The latter were less virulent in their demands, more open to working with the French rather than against them and to developing cultural and social themes of cooperation in their publications. They also tended to be led by intellectuals and members of the liberal professions. Regardless of which professions defined each community, however, black migrants were overwhelmingly male. For example, only approximately two percent of African migrants, including North Africans, were women. ${ }^{59}$

The poet Léon-Gontran Damas, the lesser-known of the founding fathers of the political and poetic movement of black francophone pride known as Négritude, explored the specificity of the black, male experience and sometimes pushed it to a brutal conclusion in a poem such as "Save Our Souls" (S.O.S.). It warns of the day when white people will no longer "be content to laugh with/their index anxious to see a nègre passing," and instead will "coldly knock out but coldly/beat up bump off knock out/cut the penis of the nègres/to make candles for their churches." 60 The collection of poems containing these sentiments, Pigments (1937), is replete with such angry frustration and with the desire to break free from French civilization. In this vein "So Often" evokes how "So often my race sentiment scares me/I feel ready to froth always with rage/against that which surrounds me/against that which keeps me/for ever from being/a man." ${ }^{61}$ Both these excerpts show how throughout this volume Damas reflected upon the manner in which black men's experiences in metropolitan France threatened to immobilize 
them and suppress their manhood. Damas was a Négritude poet, but his examination of manhood overlapped with the daily language of black migrants, which can be traced through government records that focused upon the antiimperial organizations controlled by black men.

Anti-imperialists in the metropole developed much of their anti-French rhetoric as a reaction against the experiences of colonial soldiers during World War I, even when they were not personally former soldiers. The understanding that France had denied them rights-including citizenship - that the blood some of them shed during the war should have guaranteed them, reinforced the rhetoric of injustice with which they expressed the lack of control they experienced in mainland France. ${ }^{62}$ A typical litany of complaints read much like this one, established during an April 1928 meeting of the LDRN: "the disablement pension for a nègre is a ninth of that of a white man; the disabled, the wounded lack medical care; war widows and orphans lack pensions. The indigène has to pay, suffer and die, heartsick: the Chamber refused him the right to vote." ${ }^{63}$ This sense of injustice unified black colonial milieus, becoming a consistent complaint during the 1920s. The Chamber in question was filled with senators, all white men who, by refusing them suffrage, placed the great majority of migrants from the colonies in direct opposition to European migrants, most of whom could at least vote in their countries of origin. Migrants from the colonies were thus in the distinctive position of legally resembling French women ${ }^{64}$ Indeed, that same Chamber continuously voted against allowing French women to vote even though women's war sacrifices, such as hard work and loss of husbands, sons, and fathers, seemed to women an irrefutable argument in favor of that right. Thus when the LDRN was constituted in 1927, it appeared within the logic of the association's reason for existence that the statutes should state: "all blacks without distinction of nationality and white women married to nègres can belong to the association. "65 The LDRN was meant to be dominated by black men, angry at an inequality under French law that was thrown into sharp relief for them by experiences in World War I trenches. Yet white women — who ultimately had similar gripes with the policies of the French Third Republic —were accepted. During general meetings few or, more commonly, no white men were present, but white women were a constant .66 Their presence alone, however, does not explain why French women were written into the bylaws of the organization. Putting aside for a moment the fact that in the end African, Antillean, and French women proved themselves to be active members of several of these organizations: what role were French women meant to fulfill in the LDRN? ${ }^{67}$

The answer to this question lies in part with informants, present at anti-imperialist meetings, who showed a keen interest in recording the precise words uttered during struggles internal to the black communities. According to one anti-imperialist leader from the French Sudan (today Mali), Tiémoko Garan Kouyaté, the LDRN had become the "most powerful resistance organization for black men in the Metropole" and because of this standing Kouyaté's enemies, "jealous of his prestige ... began their smear campaign ." emphasized the power and "prestige" that he associated with anti-imperialism and contrasted it with the underhanded, back-stabbing, and therefore effeminate “smear” techniques used by anti-imperialism's adversaries. His choice of words was typical. In January 1932, an LDRN member named Bourneton accused leaders of "showing signs of weakness" in the anti-imperial struggle.$^{69}$ In February of that year the LDRN's treasurer, the communist Stéphane Rosso, reproached Kouyaté with having "shamefully capitulated” when, in the context of an ongoing investigation during which a judge ordered him to hand over lists with the names and addresses of all LDRN members, Kouyaté had complied .70

Such language also peppered debates opposing workers and intellectuals. In 1928, black men went through one of several divisive political clashes. This particular one led some black intellectuals to move away from the LDRN and to create a newspaper in which they felt comfortable express-ing themselves: La Dépêche africaine. During the split, acrimonious debates divided both factions. In an early meeting of La Dépêche africaine's bureau a Haitian man "accused his compatriots of letting themselves go; Lacombe - another Haitian-defended the 'honor' of his compatriots. "71 Also in con-junction with the creation of this newspaper, Cressan, a writer for La Dépêche africaine who was frustrated by how completely the paper had moved away from the more virulent demands of the working-class anti-imperialists, at-tended a meeting of the rival LDRN's bureau to complain that La Dépêche africaine’s chief editor, Maurice Satineau, "wants to run the whole show; he is now emasculating the prose of others, or refusing articles ... because of their violence."72 Thus African and Antillean men were clearly goading one another toward particular political positions with language that 
referenced "honor," power, and "violence.” Moreover, they contrasted such vigorous terms with words evoking docility, including shame, "weakness," and, most unequivocally of all, emasculation.

Strong language coincided, occasionally, with gestures. For example in July 1929 Kouyaté and a man named Pétrus started a "violent" fight over Lucie Cousturier. She had passed away in 1925, but was remembered by migrants from the colonies as a woman who had given money to colonial organizations such as the Union Intercoloniale, and who had invited colonized men and women to her home and supported their anti-imperialism. The fight resulted from Kouyaté's suggestion that the LDRN send a delegation to Cousturier's tomb on the anniversary of her death and place a wreath on it in her memory, a seemingly innocuous gesture. Pétrus, however, found the act unnecessary and used "offensive words," which were unfortunately not specified, while defending his perspective. According to a police spy observing the argument, when Kouyaté tried to silence Pétrus, the latter escalated the "violent discussion [which] ended in an exchange of blows" after Pétrus "hit [Kouyaté] in the face," prompting Kouyaté in turn to defend himself .73

Such exchanges often centered upon white women and might have had the potential to dissuade them from ever attending meetings. Yet whereas white men were not even mentioned as potential members, white women were deliberately included in the LDRN as long as they were wives. This suggests that women were welcome on the one hand because they were not quite the true oppressors (after all they did not have the vote). On the other hand, as wives they were at least partially under the control of their black husbands, if only because they could not be present without the bond of marriage. In other words, a hierarchy kept black men firmly in control of their organization. Yet women also had a role to play as witnesses on the sidelines of spaces made all the more masculine by the tightly monitored feminine presence. The fact that quite a bit of thought went into deliberately writing white wives into the bylaws was made clear in 1932. Not all black migrants inherently presumed that French wives should be present at their meetings. Therefore at one of the opening gatherings of the antiimperialist organization that followed upon the LDRN's heels - the UTN-members started debating whether or not to allow white women into the organization: in other words, whether or not to leave in place the standards set by the LDRN.

Police documents, even read against the grain, allow only for a biased and partial perspective on black men's conceptions of their relation to white women. As a result, works by a novelist such as the African-American author Claude McKay can give us some additional insight into the debates relating to French women that raged among Africans and Antilleans. McKay's autobiography A Long Way From Home (1937) overlaps in interesting ways with his novel Banjo (1932). Both works focus on the Africans and Antilleans of the port, docks, and slums of Marseille. ${ }^{74}$ McKay reveals that marriage between white women and black activists was discussed in Marseille bars, including in one owned by a Senegalese man. ${ }^{75}$ In McKay's memoirs the café owner and an anti-imperialist leader who preceded Kouyaté, Lamine Senghor, had a conversation about such relationships. Senghor had a white wife, something the café owner found objectionable. Senghor argued that having a white spouse had made him even more aware of the constraints of the black man's condition. The café owner contended that in marrying a white woman, Senghor risked alienating black women from his cause. Just after this exchange, the café owner's white, female partner entered and "leaned affectionately upon his shoulder," leaving both Senegalese men and McKay as a witness to the exchange, rather discomfited. The conflict between emotions and politics was thrown into sharp relief by this odd juxtaposition of a political debate on the racial implications of marriage, and a demonstrative, loving woman.

In McKay’s novel Banjo, a writer named Ray continues the theme of this conversation while sitting in a bar owned by an African man (possibly the same bar mentioned in McKay's memoirs). Ray introduces a third perspective on interracial relationships. Just like the café owner he references Senghor, but categorically balks at the latter's marriage to a white woman:

I can't understand an intelligent race-conscious man doing it. Especially a man who is belly-aching about race rights. He is the one who should exercise a certain control and self-denial of his desires. Take Senghor and his comrades in propaganda for example. They are the bitterest and most humorless of propagandists and they are all married to white women. ${ }^{76}$

Senghor, the café owner and the character Ray have one thread in common: they all presumed that relationships between black men and white women were political and should be read in light of metropolitan and international power struggles. 
Back in Paris, Léon-Gontran Damas, the poet who so powerfully articulated his struggle with the repressive aspects of colonialism and race relations, discussed in his journalistic prose the dangers of politicizing relationships between black men and white women. He recognized that an "irritating [form] of race prejudice" targeted them, but also noted that in the francophone case there were very few such relationships. ${ }^{77}$ Such liaisons, he argued, "are only contracted when they favor communities of interests that they strengthen. It is this community of interests that they [detractors] are striving to annihilate at any price" (emphasis in original). ${ }^{78} \mathrm{~A}$ community of common interests absorbing white women and black men, and tied by marital and emotional bonds, was particularly threatening for colonizers. Yet Damas urged "for the white woman to be [considered] a woman and not the sex of another race."79 Those, he argued, who presumed sexuality was politics would find themselves engaging in a "counter-racism" against which he warned readers. Although Damas did not reference this example, the Vietnamese tirailleur who demanded fellatio of a white prostitute who represented France exemplified the dangers of such a "counter-racism." Instead of constructing the white woman as taboo, Damas argued, she should be perceived as merely female. Of course, what might appear a dispassionate call to order nonetheless turned the colonial hierarchy on its head, since Damas refused to consider any woman as being of a particular race, and hence forbidden to him.

In partial contrast, McKay presented interracial relationships as decisively and explicitly political gestures, and observed that black men going beyond passing sexual encounters with white women and leaning toward marriage would be challenged from within the black community. Still, both writers agreed that a crucial component of how black men constructed their interwar, metropolitan communities was through their consideration of white women. Components of all these arguments probably informed the debates among UTN members in Paris before they ultimately voted to allow the white wives of black members to join their association, thus continuing the traditions previously established by the LDRN. ${ }^{80}$ White men remained pariahs who were not accepted in these milieus.

Black communities worked to reverse traditional colonial relations of power, thereby contesting the hierarchies that defined colonialism and threatened to emasculate African and Antillean men in France. As the language and gestures of black men reveal, anti-imperial spaces were controlled by black men who paid particular attention to gender and class along with race. As wives, white Frenchwomen were political appendages, Senghor suggested in McKay's memoirs, who challenged received notions that races should not mix. McKay’s character Ray confirmed that interracial relationships were political, arguing that marriage to a white woman could weaken the black race whereas sex, a more passing engagement, was acceptable. ${ }^{81}$ As Lucie Cousturier intimated, white women in France were also analogous to black men in their lack of political rights. Indirectly, Damas acknowledged her perspective when suggesting that the taboo against interracial sexuality stemmed in part from the (white, male) administration's fear that communities of sociopolitical interests would be bolstered by intimate relationships. For all these reasons, these white wives were perceived as unthreatening, but not unproblematic, delineations of the masculine spaces constructed by black men. They were, moreover, specifically incorporated even after many intellectuals of color had fled, or arguably had been chased from, the work-ing-class milieus in and after 1928. Of course, white women were not voice-less within these organizations even if bylaws stated that their presence was made possible only by their attachment to African or Antillean husbands.

Nonetheless, black African and Antillean men in France pressed for firm control over such associations, thereby challenging in the metropole white men and women's dominance of hierarchies. They did so using a logic and tactics remarkably similar to those employed to challenge hierarchies in Cochinchina and French West Africa. Black men in France hoped to imbue the colonial spaces of metropolitan France with the power necessary to destabilize French imperialism, and through this gesture to garner honor, including that which came from carrying out race politics in the metropolitan spaces they sought to dominate.

\section{Women's Suffrage in French West Africa}

The dynamics of race and gender in the metropole were not a reflection of social realities in the colonies. Although there was an era of unprecedented solidarity among people from the French colonies in Paris during the 1930s, in French West Africa the dynamics were different. White French citizens were the minority, there was a strong tradition of Muslim power, and African women — scarce in Paris at the time-were a significant presence. 
African women had been at the bottom of the social and political hierarchy through-out the colonial era. An explicit example of the way hierarchies based on race and territorial origin functioned was the unfolding of women's political inclusion in la plus grande France.

Data from the National Archives in Dakar, Senegal—including police surveillance reports and letters confiscated by colonial administrators about the inclusion of African women in suffrage rights-reveals the deeply held racial and gendered ideas about African women by French administrators, the anxiety about rebuilding a French empire after World War II, and the role of male African leaders. In April 1944 women in metropolitan France finally won the right to vote. A suffrage ordinance was adopted in the anciennes colonies of Martinique, Guadeloupe, and Réunion on 20 November of that year. On 19 February 1945 the French administration issued a decree outlining which women in other overseas territories would be extended the same privileges as French male citizens. The ordinance stated in its article four:

French female citizens who are residents of French West Africa and Togo who are original citizens of the métropole, Algeria, the French Antilles, Réunion, French Guiana, Madagascar, New Caledonia, and the French establishments in Oceania ... are voters and eligible in the same conditions as French male citizens. ${ }^{82}$

In other words, African and Southeast Asian women were shut out from rights in the French empire. There was an explicit, legalized hierarchy that established white metropolitan women as the first to be enfranchised, followed by Caribbean women, and then women of North Africa, the Indian Ocean, and the South Pacific. This directly conflicted with the French colonial mission civilisatrice that was allegedly color-blind, and focused on "evolution" rather than inherent, static inferiority. Despite the optimism and rhetoric in the international community about human rights and equality or even assimilation, African women were excluded from the promises of these rights.

African men had long been associated with primitivism and a lack of civilization in the eyes of Europeans; but in the case of African women, this stereotype was even more deeply ingrained. The French were worried that if they granted citizenship to African men whose wives were not equally as assimilated, then French culture would not be properly passed down to the children. In an example of how hierarchies continued to be reinforced in the early twentieth century, in 1932 a new law had stated that wives and children could share the legal status of the man only if the entire family met the cultural standards set forth by the French colonial administration .83

Although the vast majority of African women were excluded from the French social and political structure, they nonetheless found ways to make their voices heard. Most commonly, they used the form of mass protests over a particular economic issue. For example, in 1932, women in Dahomey held a tax revolt. ${ }^{84}$ In 1933, market women in Togo also led a revolt against taxes, bringing a crowd of three thousand to five thousand people (eighty percent of whom were female) in protest to the capital .85 In 1934, Governor de Coppet stated that the administrators in Dakar should take seriously the complaint, especially from évolués in African regions outside of the privileged Four Communes of Senegal, that they were being denied citizenship and rights .86

The debate in Senegal about women's rights was deeply imbedded in the discourse about racial equality. ${ }^{87}$ Men from French West Africa were among the first to decry African women's electoral exclusion. Major figures in the Senegalese intelligentsia spoke out against this injustice. Consider for example an open letter written by Lamine Guèye, the first French African lawyer and later organizer of the Senegalese Socialist Party (PSS), to the governor general on 1 March 1945. In it, he stated that all but one "patriotic association" supported him and the right of African women to vote .88 Three days later, there were two significant public meetings in the key Senegalese cities of Dakar and Saint-Louis that talked about the need for equality of the races. Similar to the masculinist control of race-based organizations in interwar Paris, this political issue was a way for African men to assert authority in a colonial space. The real crime in the minds of the French African male intelligentsia, it seems, was not that African men could vote while African women could not, but rather that African women were denied the rights granted to other French women.

The meeting in Saint-Louis specifically pointed out that women from the French Antilles were not suffering from the same type of discrimination as African women. This unequal distribution of rights weakened the solidarity that race-based collective action and movements such as Négritude had forged before World War II. Regardless of intellectualized ideas of racial solidarity, the French empire drew clear distinctions and reinforced 
the old stereotype of the more assimilated French Caribbean. When the news of the suffrage laws was published in the French government's major legal publication, the Journal offi ciel de la république française, on 21 March 1945, protests spread across French West Africa. An article from the leftist journal Clarté from 30 March 1945 describes protests in Saint-Louis and Dakar. Gnagna Stine, a Senegalese woman activist and orator, ended one of the conferences with a plea for the plight of the Senegalese women in Wolof, the major African language spoken in Senegal. She argued that the exclusion of Senegalese women from the new electorate was even more grave, given that their husbands, sons, and brothers had just fought for France. This was a sensitive issue in West Africa because many felt that the French had unfairly drafted young men from the colonies as tirailleurs sénégalais, in regiments that were discriminated against and suffered high casualty rates. ${ }^{89}$

In an attempt to gauge the seriousness of the issue, the French colonial administration began to intercept letters about women's suffrage and record their contents. There was a fairly predictable range of reactions to African women becoming enfranchised. One embittered French administrator wrote to his parents in April 1945: "the négresses are even more ignorant and stupid than the pitiful black men, even more narrow-minded and incapable! What an inauthentic policy!"90 This writer's use of blatantly racist language reveals the dissonance between the French ideals of equality and assimilation and the reality of deeply held notions of white superiority in colonial Africa. Moreover, his outrage at the possibility of African women voting - a concept he saw as a sham, faux, inauthentic — captures what Herman Lebovics calls the desire to defi ne a "True France." "In this administrator's mind, allowing African women to vote was a dishonor to the French heritage which, despite its rhetoric, had specifi c notions of civilization and civilized peoples.

While some French administrators encouraged political participation, many were infused with racist principles about who was properly "civilized” and deserving of political rights. When René Pleven, commissioner of the colonies, wrote to Governor General Cournarie in June 1945 about the issue of African women voting, Cournarie responded that only those who were "exceptionally evolved" should be granted such a privilege. And then there were those who did not think any African was deserving of citizenship rights. A military man writing to his wife in France stated: "here things have

taken a revolting turn; I don't see these black women, these négresses, be-coming French during these past years, in rags, not yet civilized, possessing the rights that even our military women don't have. It was already a huge error to include black men. "92

Some proponents of women's suffrage avoided racial arguments alto-gether, favoring an appeal to traditional French republican virtues at a time when France was attempting to rebuild itself as a republic. An anonymous author wrote to A. Gomis, a colonial counselor in Casamance, Senegal and member of a famous métis family. Based on the opening tone of the letter, the author was in the confi dence of Gomis and watching the political scene intently. He writes in the informal French tense, indicating a closeness with the administrator and suggesting that even officials were not free from close scrutiny:

There are many things to say to you, but I will wait until you tell me that you have received this letter and that it is uncensored, as if we were suspects. You know about the many protests that we oppose regarding the recent decree that excludes Senegalese women from the right to vote. This is the question that is preoccupying us at the moment... It is very easy to say that our women are not mature and that they are mostly Muslims, but the Republic is secular and could be nothing but secular, therefore the religious question is irrelevant, regarding the evolutions of Universal Suffrage which was conceived for equality ... you have remarked the severity of our Governor of Senegal against the district chiefs .93

The author of this letter was most likely African and male (based on his phrase "our women”), and was appealing to the French ideal of égalité. Rather than mention gender specifically or tout the virtues of a female electorate, this man argued for African women's suffrage on the basis of French republican virtues.

Another letter from May 1945 reveals the lack of political involvement of European women living in French West Africa and the readiness of Senegalese women to participate:

Frankly for the first time since I've gotten here, I'm annoyed at the black voters and the majority of European women who are not going to the bal-lot boxes. Military wives are not getting registered. Wives of administrators look down on the female citizens of this country, when on the contrary the women of the 4 Communes seem very up-to-date. They are not like Muslim women whose role is erased by Arabs who constrain their women ... More-over, these women are ready like cats .94 
This letter indicates that African women were taking an active interest in politics, both domestic and international. Moreover, this excerpt also reveals French anxiety about Islam and the power of religious leaders to politically influence Muslims in the colonies. African leaders were well aware of this and addressed the issue directly. Lamine Guèye and Charles Graziani issued a statement contradicting the governor general's claim that Muslim leaders opposed women voting. ${ }^{95}$ In fact, according to a report to the Chamber of Commerce in Dakar, Senegalese political parties feared a general strike by Muslims if indigenous women were not granted equal voting rights to European women. ${ }^{96}$

Like many instances in history when the ruling elite fears the empowerment of an oppressed class, there is a clear tone of panic in letters such as this one from an official living in Dakar to his friends in France: "You could not imagine the things going on here in Dakar, it's frightening. The African Block is up against the whites and I've never seen such raging hatred ... it's no longer a question of Party but of race." ${ }^{\text {"97 }}$ In one sense, the author of this letter was right; he was cognizant of the cooperation between political parties on the issue of racial equality. Indeed, at a meeting of over 800 people (approximately 300 women and 500 men) held in Dakar in the spring of 1945, the two female representatives chosen were Soukenya Konaré, cousin of Lamine Guèye, and Ndate Yalla Fall, cousin of Galandou Diouf, to show unity between these two rival political families. ${ }^{98}$ The women's suffrage movement in French West Africa had become a question of racial equality more than women's rights, as the speeches and papers expressed outrage over white French, Antillean, and North African women being so overtly privileged over black Africans. For many, this was simply one more example of how the French ideal of "liberty" was a farce in the African context, and was one more reason to move away from colonial leadership.

The overarching support of African men during this period, however, was more indicative of increased disillusionment about the French rhetoric of racial equality than it was a commitment to women's inclusion in political life. In fact, Pascale Barthélémy points out in her work on the education of African women during the colonial period that colonial domination as exercised by the French "was conveyed by a reinforcement of masculine power, European and African, on African women."99 Perversely, the struggles for black liberation and female liberation were often used against each other rather than as complementary ideologies about basic equality and human rights.

There is limited scholarship on the experience of African women under French colonial rule, although some recent scholars such as Pascale Barthélémy ${ }^{100}$ and Babacar Fall ${ }^{101}$ provide historical context for some elite African women. Barthélémy argues that although quite limited in scope, the group of elite French African women in the public realm greatly shifted the status and self-image of African women. Both Barthélémy and Fall use extensive oral histories in an attempt to reconstruct the experience of women in the political and professional realms. ${ }^{102}$ In the African context, Saliou Mbaye's 1976 article is the only signifi cant examination of women's suffrage in Senegal. ${ }^{103}$ Mbaye traces the implications of France's delayed granting of suffrage to African women after metropolitan and Antillean women and outlines the local response to women's voting in Senegal.

Whether through schooling or through other means such as the economic strikes in the 1930s or railway strikes of 1940s, women found ways to organize and make their voices heard. Yet by the mid-twentieth century, having the right to vote, organize politically, and participate in the global arena were crucial tools for effective social reforms. Despite the French rhetoric of liberté, égalité, and fraternité, an exploration of the dynamics of the French colonial empire reveals that numerous inequalities and divisions existed throughout the empire. These divisions were not based on a simple colonizer-colonized dichotomy, but rather consisted of a matrix of gender, race, and territorial origin. African women consistently received the fewest rights, but even among African women there were hierarchies. As an epilogue deserving its own study, although women in Senegal finally gained voting rights equal to those of colonized women in the Caribbean and North Africa after significant work and protest, women in neighboring Mali did not win the right to vote until 1956 with the Loi Cadre. The hierarchies that were firmly ingrained in the laws and ideology of the colonial period shaped the power structures of the francophone world. Although there were varying social and political dynamics in French Indochina, metropolitan France, and French West Africa, there were distinct hierarchies in place that maintained ultimate control by French colonial authorities. Nonetheless, people from the colonies created movements of resistance and change, and fought to win rights within the colonial framework.

\section{Conclusion}


We have employed a collaborative methodology of transnational empire studies by using historical examples from French Indochina, metropolitan France, and French West Africa from 1914 to 1946. These case studies have uncovered the means by which French colonial authorities created competing hierarchies of race, place, and gender, as well as the ways in which colonized peoples responded to French authority and in turn created their own hierarchies. In Indochina, the French allocation of military funding after World War I established a legal and financial privileging of white families and traditionally structured families. French colonial policy, therefore, created a system of rewards that disrupted social practices. Colonial participants in this system, as well as colonized people fighting the system, reinterpreted the Third Republican ideal of color blindness to justify manipulation of the racial order. The case of African communities in metropolitan France shows that a language of manhood, which incorporated terms of praise, pride, honor, shame, and even emasculation, was used by black antiimperialists to express the passion that sustained their commitment to a political struggle against the imperial nation-state. Their language was given further substance by the community's layering of race and gender so as to protect their inner political circles from outside intrusion and to infuse their politics with

authority. By including white women, they both challenged their emasculation by white men or bourgeois men of color and upset colonial hierarchies. The story of black women in West Africa and the Caribbean illustrates how the battle for the inclusion of colonized women in new suffrage laws after World War II reveals a firmly established hierarchy based on race and territorial origin. Some of the racial solidarity forged during the Négritude era was challenged as black women from the French Caribbean were given privileges before African women. For Senegalese women, winning the right to vote was as much about countering European racism and colonial ideology as it was about female suffrage.

All three case studies indicate that colonial hierarchies were in a constant state of upheaval and were limited neither to one particular concept of gender and race, nor to one particular type of space: colonial, metropolitan, private, and public all came into play. Indeed, by distorting these categories, both French administrators and the colonized engaged in active manipulations of traditional systems as well as the tenets that served as the bases for discrimination. The focus upon the disingenuous trope of France's color blindness, in particular when it came to understanding how racial categories were managed via gender roles in colonial Saigon, illuminates why and how black and white, male and female anti-imperialists in the metropole were especially seditious in their interwar actions. By incorporating French women within anti-imperial projects that were largely guided by the unifying factors of race and class, these men challenged colonial hierarchies, as they did by assuming male leadership of the Senegalese women's suffrage movement in French West Africa. African men created tendentious spaces that challenged the very understandings of racial hierarchies that colonial administrators strove so hard to preserve in French Indochina. African spaces were remark-ably similar to the Indochinese and metropolitan French ones because in them hard-fought lines of solidarity-like the tenuous ones obtained by anti-imperialist men in the metropole-underwent continuous challenge. In all three spaces, hierarchies of race and gender were constantly reevaluated by a French state working increasingly hard to maintain its Empire. These categories were also in unremitting flux amongst colonial subjects and citizens who were relentlessly reassessing their relationship to the French imperial nation-state.

\section{Notes}

1. The authors would like to thank the readers of $H R / R H$ for their generous and thoughtful comments. Félix Germain and Tyler Stovall provided useful feedback to the conference papers at the heart of this collaboration. The authors would also like to thank Haydon Cherry, Jens-Uwe Güttel, Kenneth Loiselle, and Nata-sha Pairaudieu. The three of us have found working together a stimulating and enjoyable, collaborative exercise in feminist scholarship.

2. Approximately 134,000 black soldiers landed in Europe. Marc Michel, Les Africains et la grande guerre: l'appel à l'Afrique (1914-1918) (Paris, 2003), 191-97. Tyler Stovall explains that the number of workers from French West Africa was quite small, but that 4,546 Malagasies were mobilized as colonial workers. Tyler Edward Stovall, “The Color Line Behind the Lines: Racial Violence in France During the Great War,” The American Historical Review 103.3 (1998): 741-42. On the tirailleurs see also: Charles John Balesi, From Adversaries to Comrades-in-Arms: West Africans and the French Military, 1885-1918 (Waltham, MA: 1979); Myron Echenberg, Colonial Conscripts: The Tirailleurs Sénégalais in French West Africa, 
1857-1960 (Portsmouth, NH, 1991); Joe Lunn, Memoirs of the Maelstrom: A Senegalese Oral History of the First World War (Oxford, 1999); Gregory Mann, "Locating Colonial Histories: Between France and West Africa,” American Historical Review 110.2 (2005 ): 409-34; Gregory Mann, Native Sons: West African Veterans and France in the Twentieth Century (Durham, 2006); Tyler Edward Stovall, "Love, Labor, and Race: Colonial Men and White Women in France During the Great War," in French Civilization and Its Discontents: Nationalism, Colonialism, Race, ed. Tyler Edward Stovall (Lanham, MD, 2003), 297322; and Georges Van Den Abbeele, After the Empire: The Francophone World and Postcolonial France (Lanham, MD, 2003).

3. For example, Lucie Cousturier, Mes Inconnus chez eux: mon amie Fatou, citadine, 2 vols., vol. 1 (Paris, 1925). On Cousturier see also Brett A. Berliner, Ambivalent Desire: The Exotic Black Other in Jazz-Age France (Amherst, 2002); Roger Little, "René Maran on Lucie Cousturier, a Champion of Racial Understanding,” Re-search in African Literatures 34.1 (2003): 126-36.

4. Lucie Cousturier, Des Inconnus chez moi, [2nd ed.] ed. (Paris, 1920), 229.

5. Michael G. Vann, "The Good, the Bad, and the Ugly: Variation and Difference in French Racism in Colonial Indochine,” in The Color of Liberty, eds. Tyler Stovall and Sue Peabody (Durham, 2003), 187.

6. Michael G. Vann, "White Blood on Rue Hue: The Murder of 'le négrier' Bazin,” The Proceedings of the Western Society for French History 34 (2006): 247-62; Michael G. Vann, “Of Rats, Rice, and Race: The Great Hanoi Rat Massacre, an Episode in French Colonial History," French Colonial History, 4 (2003): 191-204; Michael G. Vann, "Building Colonial Whiteness on the Red River: Race, Power, and Urbanism in Paul Doumer's Hanoi, 1897-1902,” Historical Refl ections/ Réfl exions Historiques 33.2 (2007): 277-304.

7. Ann Laura Stoler, Race and the Education of Desire: Foucault's History of Sexuality and the Colonial Order of Things (Durham, 1995), 101-09.

8. For more on the effect of colonial rule on intimate relationships, see Ann Laura Stoler Carnal Knowledge and Imperial Power: Race and the Intimate in Colonial Rule (Berkeley, 2002); Matt Matsuda and Alice Bullard, eds., "Emotional Latitudes: The Ambiguities of Colonial and Post-Colonial Sentiment," Historical Refl ections/ Réfl exions Historiques 34.1 (2008).

9. Frederick Cooper and Laura Ann Stoler, eds., Tensions of Empire: Colonial Cultures in a Bourgeois World (Berkeley, 1997). For examples of work paying close attention to place see for example Julia Clancy-Smith, “Migrations, Legal Pluralism, and Identities: Algerian ‘Expatriates' in Colonial Tunisia,” in Algeria \& France 1800 -2000: Identity, Memory, Nostalgia, ed. Patricia Lorcin (Syracuse, NY, 2006), 3-17; Gregory Mann, "Locating Colonial Histories: Between France and West Africa," American Historical Review 110.2 (2005): 409-34; Mrinalini Sinha, "Britishness, Clubbability, and the Colonial Public Sphere: The Genealogy of an Imperial Institution in Colonial India,” The Journal of British Studies 40.4 (2001): 489-521.

10.On the former, see for example: Frederick Cooper, Colonialism in Question: Theory, Knowledge, History (Berkeley, 2005); Emannuelle Saada, Les Enfants de la colonie: Les métis de l'Empire français entre sujétion et citoyenneté (Paris, 2007); Eric Thomas Jennings, Vichy in the Tropics: Pétain’s National Revolution in Madagascar, Guadeloupe, and Indochina, 1940-1944 (Stanford, 2001); Eric T. Jennings, Curing the Colonizers: Hydrotherapy, Climatology and French Colonial Spas (Durham, 2006). On the latter: Pascal Blanchard and Sandrine Lemaire, Culture impériale 1931-1961: Les colonies au coeur de la République (Paris, 2004); Julia Ann Clancy-Smith and Frances Gouda, Domesticating the Empire: Race, Gender, and Family Life in French and Dutch Colonialism (Charlottesville, VA, 1998); Cooper and Stoler, eds, Tensions of Empire: Colonial Cultures in a Bourgeois World; Sue Peabody and Tyler Edward Stovall, eds., The Color of Liberty: Histories of Race in France (Durham, 2003); Tyler Edward Stovall and Georges Van Den Abbeele, eds., French Civilization and Its Discontents: Nationalism, Colonialism, Race (Lanham, MD, 2003).

11.A wonderful example of how such co-authorship can function is: J. A. Miller, Susan D. Pennybacker, and Eve Rosenhaft, "Mother Ada Wright and the International Campaign to Free the Scottsboro Boys, 19311934,” The American Historical Review 106.2 (2001): 387-430.

12.We first presented papers at the Western Society for French History in Albuquerque, NM on 8 November 2007.

13.Claire Duchen, “Une femme nouvelle pour une France nouvelle?” CLIO 1 (1995): 151-64. 
14.During the Middle Ages, for example, poor, unemployed men were gendered as more female than not only elite men and women, but also than poor women. Sharon Farmer, Surviving Poverty in Medieval Paris: Gender, Ideology and the Daily Lives of the Poor (Ithaca, 2002).

15.Christine Bard, Les femmes dans la société française au $20^{e}$ siècle (Paris, 2001); Mary Louise Roberts, Civilization Without Sexes: Reconstructing Gender in Postwar France, 1917-1927 (Chicago, 1994).

16.Philippe Dewitte, Les Mouvements nègres en France 1919-1939 (Paris, 1985 ); Claude Liauzu, Aux origines des tiers-mondismes: colonisés et anticolonialistes en France 1919- 1939 (Paris, 1982).

17.Duchen, "Une femme nouvelle."

18.Barbara Bush, "Gender and Empire: The Twentieth Century” in Gender and Empire, ed. Philippa Levine (Oxford, 2004), 77-111.

19.Ann Laura Stoler, Carnal Knowledge, 51; Barbara Bush, “Gender and Empire: The Twentieth Century.” It is important, however, to note that white women were "ambiguously complicit both as colonizers and colonized, privileged and restricted, acted upon and acting.” See Ann McClintock, Imperial Leather: Race, Gender and Sexuality in the Colonial Contest (New York, 1995), 6; Nupur Chaudhuri and Margaret Strobel, "Introduction" in Western Women and Imperialism: Complicity and Resistance, eds. Nupur Chaudhuri and Margaret Strobel (Bloomington, IN, 1992), 5-15. As Frances Gouda has shown, "white women” was a very diverse category. See Frances Gouda, Dutch Culture Overseas: Colonial Practice in the Netherlands Indies, 1900-1942 (Amsterdam, 1997).

20. On masculinity see Gail Bederman, Manliness \& Civilization: A Cultural History of Gender and Race in the United States, 1880-1917 (Chicago, 1995); Hazel V. Carby, Race Men (Cambridge, MA, 1998); Tim Edwards, Cultures of Masculinity (New York, 2006); Mrinalini Sinha, Colonial Masculinity: The 'Manly Englishman' and the 'Effeminate Bengali' in the Late Nineteenth Century (Manchester, 1995); Richard Smith, Jamaican Volunteers in the First World War: Race, Masculinity and the Development of National Consciousness (Manchester, 2004); Michelle Ann Stephens, Black Empire: The Masculine Global Imaginary of Caribbean Intellectuals in the United States, 1914-1962 (Durham, 2005); Martin Summers, Manliness and Its Discontents: The Black Middle Class and the Transformation of Masculinity, 1900-1930 (Chapel Hill, NC, 2004). On black masculinity in France see Justin-Daniel Gandoulou, Au coeur de la sape: moeurs et aventures des congolais à Paris (Paris, 1989); Dominic Thomas, Black France: Colonialism, Immigration, and Transnationalism (Bloomington, 2007).

21. Jane Haggis, “Gendering Colonialism or Colonizing Gender? Recent Women’s Studies Approaches to White Women in the History of British Colonialism,” Women's Studies International Forum 13 (1990): 10515. See also Janet R. Horne, "In Pursuit of Greater France: Visions of Empire among Musée Social Reformers, 1894-1931,” in Domesticating the Empire: Race, Gender, and Family Life in French and Dutch Colonialism, eds. Julia Clancy-Smith and Frances Gouda (Charlottesville, 1998), 22; Philippa Levine, “Introduction: Why Gender Empire?” in Gender and Empire, ed. Philippa Levine (Oxford, 2004), 1.

22. For example, see the case of the Caribbean in Laurent Dubois, "Republican Anti-racism and Racism: A Caribbean Genealogy," in Race in France: Interdisciplinary Perspectives on the Politics of Difference, eds. Herrick Chapman and Laura L. Frader (New York, 2004), 25-35; Saada, Les Enfants; Owen White, Children of the French Empire: Miscegenation and Colonial Society in French West Africa, 1895-1960 (Oxford, 1999).

23. On antiracism in France, see Steven Ungar, "Introduction: Questioning Identity," in Identity Papers: Contested Nationhood in Twentieth-Century France, eds. Steven Ungar and Tom Conley (Minneapolis, 1996), 1-15. For a rich discussion of social markers of citizenship see Mary Dewhurst Lewis, "Policing Migration and Nation in Interwar Marseille," in Race in France: Interdisciplinary Perspectives on the Politics of Difference, eds. Herrick Chapman and Laura L. Frader (New York, 2004), 78. For a thorough history of scientifi c racial categorizations see Claude Blanckaert, "Of Monstrous Métis? Hybridity, Fear of Miscegenation, and Patriotism from Buffon to Paul Broca," in The Color of Liberty, eds. Tyler Stovall and Sue Peabody (Durham, 2003), 42-70; William H. Schneider, Quantity and Quality: The Quest for Biological Regeneration in Twentieth-Century France (Cambridge, 1990).

24. Alice Conklin, A Mission to Civilize: The Republican Idea of Empire in France and West Africa, 18951930. (Stanford, 1997). 
25. Gary Wilder, The French Imperial Nation-State: Negritude and Colonial Humanism between the Two World Wars (Chicago, 2005), 77.

26. Joan Wallach Scott, Only Paradoxes to Offer: French Feminists and the Rights of Man (Cambridge, MA, 1996).

27. Gary Wilder argues that scholars must be wary of taking Third Republican rhetoric at face value. It is important to note that in the following cases in Cochinchina, colonial offi cials repetitively used Third Republican rhetoric at face value to make racialist arguments. Wilder, The French Imperial Nation-State, 77.

28. Ann Laura Stoler, "Rethinking Colonial Categories: European Communities and the Boundaries of Rule," Comparative Studies in Society and History 31(1989): 151-152.

29. Ho Chi Minh City, Vietnam [hereafter HCMC], Vietnam National Archives [VNNA] II, Files of the Governor of Cochinchina GouCoch 1A.5/015, Letter, GouCoch to Outrey, 12 October 1917.

30. It is not possible to compare the cost of living of whites and people of color in Cochinchina, as the statistics for these years were only recorded in Hanoi. See Gouvernement général de l'Indochine, Annuaire Statistique de L'Indochine, Pre-mier Volume Recueil de Statistiques relatives aux années 1913 à 1922 (Hanoi, 1927), 196-97.

31. Files on Madame Marie Agnes B. in the Minutes of the Commission in charge of examining the demands for allocation in favor of the reservists' families, HCMC, VNNA II, Files of the GouCoch 1A.5/234(1), 39th meeting, 4 February 1918.

32. HCMC, VNNA II, Files of the GouCoch 1A.5/215, Letter, Madame G. to the Mayor of Saigon, no date, approximately July 1916.

33. HCMC, VNNA II, Files of the GouCoch 1A.5/015, Letter Marie A. to GouCoch, October 1916; HCMC, VNNA II, Files of the GouCoch 1A.5/015, Note, Central Police of the City of Saigon, 16 October 1916; HCMC, VNNA II, Note, Files of the GouCoch 1A.5/015, Letter, Marie A. to GouCoch, 1 October 1916.

34. Christina Firpo “"The Durability of the Empire': Race, Empire, and 'Abandoned' Children in Colonial Vietnam 1870-1956” (Ph.D. Diss., University of California at Los Angeles, 2007).

35. HCMC, VNNA II, Files of the GouCoch 1A.5/015, Letter, GouCoch to Outrey, 12 October 1917.

36. HCMC, VNNA II, Files of the GouCoch 1A.5/234(1) Files L., Minutes of the Commission in charge of examining the demands for allocation in favor of the reservists and mobilized soldiers, 35th meeting.

37. Files on B., HCMC, VNNA II, Files of the GouCoch 1A.5/234 (1), Minutes of the Commission in Charge of Examining the Demands for Allocation in Favor of Reservists' Families, 28th Meeting, 11 May 1917.

38. HCMC, VNNA II, Files of the GouCoch 1A.6/015, Letter, Mayor of Saigon to GouCoch, 3 May 1916.

39. HCMC, VNNA II, Files of the GouCoch 1A.5/234(1) Minutes of the Commission in charge of examining the demands for allocation in favor of the families of reservists, 41st meeting, 26 April 1918.

40. HCMC, VNNA II, Files of the GouCoch 1A.5/212(3), Note, "Reservist Soldier," 15 May 1915.

41. HCMC, VNNA II, Files of the GouCoch 1A.5/234(1) Minutes of the Commission in Charge of examining the demands for allocation in favor of reservists families, 40th meeting, 21 March 1918.

42. HCMC, VNNA II, Files of the GouCoch 1A.6/015, Letter. Paul B. to Minister of Colonies, April 1915.

43. HCMC, VNNA II, Files of the GouCoch 1A.6/015, Letter Minister of Colonies to Paul B., 25 August 1915.

44. HCMC, VNNA II, Files of the GouCoch 1A.6/015, Telegram, GouCoch to GGI, 21 October 1915.

45. HCMC, VNNA II, Files of the GouCoch 1A.6/015, Letter, GouCoch to unknown, 19 November 1915.

46. See Woman-Nation-State, eds. Nira Yuval-Davis and Gloria Anthias (London, 1989), 1-15.

47. Stovall, "Color Line," 766.

48. The tradition of considering the place of women within republican spheres, including the danger that they might feminize these spheres, naturally predates the twentieth century. Jean-Jacques Rousseau in particular, but also John Locke, influenced considerations of the private and public places of women. Both French republicans specifi cally and French men more generally mulled over these questions well into the nineteenth and twentieth centuries. See Carol Blum, Rousseau and the Republic of Virtue: The Language of Politics in the French Revolution (Ithaca, 1989); Dena Goodman, The Republic of Letters: A Cultural History of the French Enlightenment (Ithaca, 1996); Joan B. Landes, Women and the Public Sphere in the Age of the French Revolution (Ithaca, 1988); Robert A. Nye, Masculinity and Male Codes of Honor in Modern France (New York, 1993); Carol Pateman, The Sexual Contract (Stanford, 1988). 
49. Stovall, "Love, Labor, and Race,” 298.

50. Richard S. Fogarty, Race and War in France: Colonial Subjects in the French Army, 1914-1918, ed. Michael Fellman, War/Society/Culture (Baltimore, 2008), 202-29.

51. Aix-en-Provence, Centre des Archives d'Outre-Mer (hereafter CAOM), SLOTFOM VI/7, Le contrôleur Pech à Monsieur le Ministre des Colonies, 15 October 1917. See also the case of Alphonse Tchikoundji in CAOM, SLOTFOM, VI/7, Gouverneur Général de l’AEF à Monsieur le Ministre des Colonies, 8 May 1925.

52. See, for example, the case of Vu Van Dung and demoiselle Perrot in CAOM, SLOTFOM VI/7, Ministère de la Guerre à Monsieur le Ministre des Colonies (Services Militaires), Bordereau d’Envoi no. 59, 28 March 1922.

53. CAOM, SLOTFOM VI/7, Le Ministre des Colonies à Monsieur le Ministre de la Guerre (8ème Direction 3ème Bureau), 30 May 1922.

54. On French motivations with respect to this regulation of colonized men's love lives see Richard S. Fogarty, "Race and Sex, Fear and Loathing in France during the Great War," Historical Refl ections/Réfl exions Historiques 34.1 (2008): 51; Stovall, "Love, Labor, and Race.”

55. CAOM, SLOTFOM XI/1, Général de Division Andlauer, Commandant Supérieur des Troupes du Groupe de l’Indochine à Monsieur le Ministre de la Guerre 8e Direction, Hanoi, 15 March 1926.

56. Examples of transcolonial anti-imperial organizations include the Union intercoloniale, the Ligue des droits de l'homme, and, of course, the Ligue anti-impérialiste. Robbie Aitken, "From Cameroon to Germany and Back via Moscow and Paris: The Political Career of Joseph Bilé (1892-1959), Performer, 'Negerarbeiter' and Comintern Activist," Journal of Contemporary History 43.4 (2008): 597-616; Jennifer Anne Boittin, "Black in France: The Language and Politics of Race during the Late Third Republic," French Politics, Culture \& Society 27.2 (2009): 23-46; Claude Liauzu, Aux origines des tiers-mondismes: Colonisés et anticolonialistes en France 1919-1939 (Paris, 1982); Erica J. Peters, "Resistance, Rivalries, and Restaurants: Vietnamese Workers in Interwar France,” Journal of Vietnamese Studies 2.3 (2007): 109-43.

57. The CDRN was founded in March 1926 and split into two organizations in 1927. The LDRN was founded in 1927 out of the more radical of the two splinter groups, but later became contested by two factions. The UTN was founded in

June 1932 shortly after the LDRN was dismantled, and with much the same membership.

58. The intellectuals were particularly drawn to this approach. See Edward O. Ako, "L'Etudiant Noir and the Myth of the Genesis of the Negritude Movement,” Research in African Literatures 15.3 (1984): 341-53; Jean Pandolfi , "De Légitime défense à Tropiques: Invitation à la découverte," Europe: Revue Littéraire Mensuelle (1980): 97-107.

59. Georges Mauco, Les Étrangers en France: Leur rôle Dans l'activité économique (Paris, 1932), 175.

60. Léon-Gontran Damas, Pigments (Paris, 1937).

61. Ibid.

62. Philippe Dewitte, Les Mouvements nègres en France 1919-1939 (Paris, 1985), 17- 54.

63. CAOM, SLOTFOM III/88, Notes sur la propagande révolutionnaire intéressant les pays d'Outre-Mer (hereafter PROM), April 1928: 7.

64. On immigration in modern France, see for example Louis Chevalier, Classes laborieuses et classes dangereures à Paris pendant la première moitié du Xixe siècle (Paris, 1984); Mary Dewhurst Lewis, The Boundaries of the Republic: Migrant Rights and the Limits of Universalism in France, 1918-1940 (Stanford, 2007); Gérard Noiriel, Le Creuset français: histoire de l'immigration, Xix-Xxe Siècle (Paris, 1992, c1988); Clifford Rosenberg, Policing Paris: The Origins of Modern Immigration Control between the Wars (Ithaca, 2006); Todd Shepard, The Invention of Decolonization: The Algerian War and the Remaking of France (Ithaca, 2006); Maxim Silverman, Deconstructing the Nation: Immigration, Racism, and Citizenship in Modern France (London, 1992); Paul A. Silverstein, Algeria in France: Transpolitics, Race, and Nation (Bloomington, IN, 2004); Alexis Spire, Etrangers à la carte: L'administration de l'immigration en France, 1945-1975 (Paris, 2005).

65. Paris, Archives Nationales (hereafter AN), F/7/13166, PROM, April 1927: 17.

66. AN, F/7/13167, PROM, July 1929: 13. 
67. Both colonized women and the white wives of anti-imperialists found ways to express themselves in interwar France. See Jennifer Anne Boittin, "In Black and White: Gender, Race Relations and the Nardal Sisters in Interwar Paris,” French Colonial History 6 (2005): 119-135; T. Denean Sharpley-Whiting, Negritude Women (Minneapolis, 2002); Robert P. Smith, Jr., "Black Like That: Paulette Nardal and the Negritude Salon,” CLA Journal 45.1 (2001): 53-68.

68. AN, F/7/13168, PROM, June 1932.

69. AN, F/7/13186, PROM, January 1932: 9.

70. AN, F/7/13168, PROM, February 1932: 12.

71. CAOM, SLOTFOM III/88, PROM, March 1928: 12.

72. AN, F/7/13166, PROM, October 1928: 7.

73. AN, F/7/13167, PROM, July 1929: 9.

74. Yaël Simpson Fletcher, "Unsettling Settlers: Colonial Migrants and Racialised Sexuality in Interwar Marseilles,” in Gender, Sexuality and Colonial Modernities, ed. Antoinette Burton (New York, 1999): 7994; Mary Dewhurst Lewis, "The Company of Strangers: Policing Migration and Nation in Marseille," French Politics, Culture \& Society 20.3 (2002): 65-96.

75. See for example AN, F/7/13168, PROM, July 1931: 6.

76. Claude McKay, Banjo (London, 2000), 179.

77. Leon-Gontran Damas, "Misère Noire," in Retour de Guyane: Suivi de "Misère Noire" et autres écrits journalistiques, ed. Sandrine Poujols (Paris, 2003), 173-174. The original article was published in: Esprit 81 (June 1939).

78. Ibid., 174.

79. Ibid., 175.

80. CAOM, SLOTFOM III/53, Agent Joe, 5 September 1932.

81. McKay, Banjo, 177-79.

82. Saliou Mbaye, 1976. “Le vote des femmes au Senegal,” Ethiopiques 6 (April): 36.

83. Wilder, French Imperial Nation-State, 132.

84. Ibid., 122.

85. Benjamin N. Lawrance. “La Revolte des femmes,” African Studies Review 46.1 (2003): 47.

86. Wilder, French Imperial Nation-State, 122.

87. An articulated movement for women's rights within Senegal that challenged male dominance did not really occur until the 1970s. See, for example, Awa, "Emancipation: La revolte grande: reunis à Paris 300 femmes noires ont rejette le colonialisme de l’homme,” Bingo January 1978, no. 300. Archives Nationales du Senegal (ANS), Bi II 4.150.

88. Mbaye, "Le Vote des femmes,” 38.

89. Echenberg, Colonial Conscripts, 103.

90. ANS, 17 G 415 126. Letter intercepted 1 May 1945. Gayraud to parents.

91. Herman Lebovics, True France: The Wars Over Cultural Identity, 1900-1945 (Ithaca, 1992).

92. ANS, 17 G 415 126. Letter intercepted 22 June 1945. Chipot to wife Mme Chipot.

93. ANS, 17 G 415 126. Letter intercepted 10 April 1945. Unknown author to Gomis.

94. ANS, 17 G 415 126. Letter intercepted 3 May 1945. Unknown author to Astay, mayor of Blida in Algeria. "Ready like cats" is the direct translation, presumably meaning eager or ready to pounce.

95. Mbaye, "Le Vote des femmes," 42.

96. ANS, 17 G 415 126. Report 28 March 1945. Comandant Bonifay to president of the Chamber of Commerce in Dakar.

97. ANS, 17 G 415 126. Letter intercepted 26 June 1945. Unknown author to Mme et M Caragnon.

98. Mbaye, “Le Vote des femmes,” 39.

99. Pascale Barthelemy, "Sages-femmes africaines diplômees en AOF des annees 1920 aux annees 1960," in Anne Hugon, ed. Histoire des femmes en situation coloniale: Afrique et Asie, XXe siècle (Paris, 2004), 119. 100. Pascale Barthelemy, "La Professionalisation des Africaines en AOF (1920-1960),” Vingtième Siècle: Revue d'histoire 75 (1992): 35-46, and Barthelemy, "Sages-femmes africaines diplômees,” 119-44. 
101. Babacar Fall, "Social History in French West Africa: Forced Labor, Labor Market, Women and Politics," Sephis-CSSSC publication 1 (2002), http://sephis.org/ node/301.

102. Ghislaine Lydon and Claire H. Griffi ths have each drawn attention to the signifi cance of Denise Savineau's 1938 "Report on Women and the Family in French West Africa” as a source for understanding the experience of African women under French colonial rule. See Ghislaine Lydon, "The Unraveling of a Neglected Source: Women in Francophone West Africa in the 1930s,” Cahiers d'Etudes Africaines 147.37 (1997): 555-84, and Claire H. Griffi ths, "Colonial Subjects: Race and Gender in French West Africa: An Annotated Translation and Presentation of Denise Savineau's Report on Women and the Family in French West Africa, 1938,” International Journal of Sociology and Social Policy 26.11-12 (2006): 449-594. 103. Mbaye, “Le vote des femmes.” Ethiopiques 6 (April 1976): 26-43. 